
\title{
.
}

\section{ASSESSMENT OF ANTHROPOMETRIC AND IRON STATUS OF SCHOOL CHILDREN IN SOMOLU LOCAL GOVERNMENT AREA OF LAGOS STATE, NIGERIA}

\author{
Ifebajo, A.Y ${ }^{1}$, Afolabi, W.A.O. ${ }^{1}$, Sanni, S.A. ${ }^{1}$, Onabanjo, O.O. ${ }^{1}$ and Ariyo, A.M. ${ }^{2}$
}

1. Department of Nutrition and Dietetics, Federal University of Agriculture, Abeokuta

2. Department of Home Science and Management, Federal University of Agriculture, Abeokuta

Correspondence: preciousyettyesther@gmail.com, Tel: +234802 8346290

\section{ABSTRACT}

Iron is essential for children's cognition because it enhances behavioural and intellectual performance and promotes the body's resistance to infections. However, the risk of iron deficiency increases during period of rapid growth notably among school aged children in developing countries. This study assessed the anthropometric and iron status of school children in Somolu Local Government Area of Lagos State. Somolu Local Government was selected using purposive sampling. One hundred and forty school children (8-12 years) were selected from 3 primary schools using multistage sampling technique. Socio economic data were collected using structured questionnaire. Nutritional status of pupils were assessed using anthropometric measurements while iron status was determined using biochemical analyses of serum ferritin (SF), packed cell volume (PCV) and haemoglobin (H-B). Socio economic data were analysed with descriptive statistic (frequency, mean and percentages). While Chi-square and Pearson product moment correlation were used to establish relationship between variables. Pattern of dietary iron sources intake of the respondents were determined using food frequency questionnaire. Result showed that mean values of weight, height, haemoglobin, packed cell volume and ferritin were $43.82 \mathrm{~kg}$, $141.67 \mathrm{~cm}, 11.50 \mathrm{~g} / \mathrm{dl}, 33.91 \%$ and $49.10 \mathrm{ng} / \mathrm{l}$ respectively. Results of Anthropometric assessment indicated that $18.2 \%$ of female and $12.7 \%$ male were stunted; $15.6 \%$ of female and $14.30 \%$ of male were wasted, while $27.3 \%$ of the female and $23.0 \%$ of the male were underweight. $67 \%$ of the subjects had normal ferritin (15-100ng/l), 19.0\% had low ferritin $(<15 \mathrm{ng} / \mathrm{l})$ while $14.3 \%$ had abnormal high ferritin $(>100 \mathrm{ng} / \mathrm{l})$. The respondents (14.3\%) whose ferritin level were exceedingly high (>100ng/l) belong to AC (4.7\%), SC $(3.5 \%)$, and SS $(6.1 \%)$ genotype blood groups. Findings also revealed that $24.2 \%$ of the male and $33.0 \%$ of female respondents were anaemic $(\mathrm{Hb}<11 \mathrm{~g} / \mathrm{dl}) .81 .43 \%$ of the respondents consume less of iron rich food. The haemoglobin levels of the male respondents were found to be positively correlated with their BMI. ( $\mathrm{r}=0.289, \mathrm{P}>0.05)$. There was a positive correlation between PCV and BMI of male respondents $(\mathrm{r}=0.209 ., \mathrm{P}<0.05)$. Furthermore, there was a relationship between blood Ferriftin and genotype of both male and female respondents respectively $(\mathrm{r}=0.276, \mathrm{P}<0.05),(\mathrm{r}=0.341, \mathrm{P}<0.05)$. A positive correlation existed between ferritin and food intake pattern of female respondents $(r=0.288, P<0.05)$. There was a negative correlation between iron status and income of the respondents' parents, $\quad(r=0.276$, $\mathrm{P}<0.05$ ). In conclusion, this study has ascertained that there is stunting, wasting, underweight and iron deficiency among school children in Somolu Local Government Area of Lagos State. It is recommended that appropriate intervention should be introduced to reduce the prevalence of iron deficiency among school aged children in Somolu Local Government Area.

Keywords: Iron, Serum Ferritin, Anthropometric, Packed Cell Volume 


\section{INTRODUCTION}

Iron is one of the most abundant metals on earth which is essential to most life forms and to normal human physiology (Dallman 1986). Every living cell - both plant and animal contains iron. Most of the iron in the body is a component of the proteins haemoglobin in red blood cells and myoglobin in muscle cells. The iron in both haemoglobin and myoglobin helps to carry and hold oxygen and then release it (Bothwell et. al., 1999).

Iron is a vital component of haemoglobin, the protein in red blood cells responsible for transporting oxygen to cells for the production of energy. It's integral to the formation of collagen and other proteins, and also helps transform beta-carotene into vitamin A. Iron is widely available in foods, and comes in two forms - heme and non heme. Heme iron is found in animal tissue including meat, poultry and fish, while non heme iron occurs in egg yolks and foods of plant origin. Legumes are excellent sources of non heme iron

Iron is a mineral that is naturally present in many foods, added to some food products, and available as a dietary supplement. Iron is an essential component of haemoglobin, an erythrocyte protein that transfers oxygen from the lungs to the tissues (Wessling Resnick, et. al., 2014). As a component of myoglobin, a protein that provides oxygen to muscles, iron supports metabolism (Agget et. al., 2010). Iron is also necessary for growth, development, normal cellular functioning, and synthesis of some hormones and connective tissue (Agget et. al., 2010, Murray-Kolbe et. al., 2010).

Dietary iron has two main forms: heme and non heme (Wessling Resnick, et. al., 2014). Plants and iron-fortified foods contain non heme iron only, whereas meat, seafood, and poultry contain both heme and non heme iron (Agget et. al., 2010). Heme iron, which is formed when iron combines with protoporphyrin IX, contributes about $10 \%$ to $15 \%$ of total iron intakes in western populations (Murray-Kolbe et. al., 2010, Hurrel 2010, Drakesmith 2012).

Haemoglobin in the blood carries oxygen from the lungs to tissues throughout the body. Myoglobin holds oxygen for the muscles to use when they contract (Marsh, 1992). As part of many enzymes, iron is vital to the processes by which cells generate energy. Iron is also needed to make new cells, amino acids, hormones and neurotransmitters. It is essential for the regulation of cell growth and differentiation (Bothwell et. al., 1999). A deficiency of iron limits oxygen delivery to cells resulting in fatigue, poor work performance and decreases immunity (Hass and Bhaskaram, 2001). On the other hand excess amounts of iron can result in toxicity and even death (Corbett, 1995).

Most of the 3 to 4 grams of elemental iron in adults is in haemoglobin (Agget et. al., 2010). Much of the remaining iron is stored in the form of ferritin or hemosiderin (a degradation product of ferritin) in the liver, spleen, and bone marrow or is located in myoglobin in muscle tissue (Wessling Resnick, et. al., 2014, Drakesmith and Patience 2012). Humans typically lose only small amounts of iron in urine, feces, the gastrointestinal tract, and skin. Losses are greater in menstruating women because of blood loss. Hepcidin, a circulating peptide hormone, is the key regulator of both iron absorption and the distribution of iron throughout the body, including in plasma (Wessling Resnick, et. al., 2014, Agget et. al., 2010, Drakesmith and Patience 2012). 
Iron is also found in proteins that store iron for future need and that transport iron in blood. Iron stores are regulated by intestinal iron absorption.

\section{FOOD SOURCES OF IRON}

There are two forms of dietary iron: heme and non-heme. Heme iron is derived from haemoglobin, the protein in red blood cells that delivers oxygen to cells. Heme iron is found in animal foods that originally contained haemoglobin such as red meats, fish and poultry. Iron in plant foods such as lentils and beans is arranged in a chemical structure called non heme. Heme iron is absorbed better than non heme iron, but most dietary iron is non heme iron. Most of the iron people consume is non heme iron from vegetables, grains, eggs, meat, fish and poultry (Hurrel, 1997).

Iron absorption from foods can be maximized by two substances that enhance iron absorption. Meat, fish and poultry contain a factor (MFP factor other than heme that promotes the absorption of iron. MFP factor even enhances the absorption of non heme iron from other foods eaten at the same time. Vitamin $\mathrm{C}$ eaten in the same meal also doubles or triples non-heme iron absorption (Hurrel, 1997).

Additionally, cooking with iron skillets can contribute iron to the diet. Some substances impair iron absorption; they include the tannis of tea and coffee, the calcium in milks and the phytates that accompany fibrin in legumes and whole grain cereals (Corbett, 1995; Cook et. al., 1997).

Supplement are widely available but should never be taken unless recommended by a nutritionist or medical practitioner - the first route should be your diet, "meat contains the most bioavailable form of iron called heme -iron and red meat contains the most although darker poultry meat and oily fish are also good sources" says Weich Seldaum (2000). He continued that spinach is not the best option. It contains substances called phytates that block the absorption of iron from the body. He added that if you don't eat much meat make sure you eat plenty of Vitamin $\mathrm{C}$ rich foods such as fresh fruits juice vegetables or a bowl of strawberries; it helps with the absorption of iron from the rest of the diet. Other good sources include fortified breakfast cereals.

\section{IRON STATUS}

The risk of iron deficiency increases during periods of rapid growth, notably in infancy, adolescence and pregnancy. The consequences of iron deficiency include reduced work capacity, impaired body temperature and regulations, impairments in behaviour and intellectual performance and decreased resistance to infections. Iron deficiency results when ingestion or absorption of dietary iron is inadequate to meet iron losses or iron requirements imposed by growth or pregnancy. 
In most individuals the concentration of serum ferritin equals the total amount of storage iron, and serum ferritin is the only iron status index that can reflect a deficient excessive and normal iron status (Nigeria Food Consumption and Nutrition Survey 2001 - 2003).

Many different measures of iron status are available, and different measures are useful at different stages of iron depletion. Measures of serum ferritin can be used to identify iron depletion at an early stage (Gibson, 2005; Drakesmith and Patience, 2012). A reduced rate of delivery of stored and absorbed iron to meet cellular iron requirements represents a more advanced stage of iron depletion, which is associated with reduced serum iron, reticulocyte haemoglobin, and percentage transferrin saturation and with higher total iron binding capacity, red cell zinc protoporphyrin, and serum transferrin receptor concentration. The last stage of iron deficiency, characterized by iron-deficiency anaemia (IDA), occurs when blood haemoglobin concentrations, hematocrit (the proportion of red blood cells in blood by volume), mean corpuscular volume, and mean cell haemoglobin are low (Agget et. al., 2010,WHO 2012). Haemoglobin and hematocrit tests are the most commonly used measures to screen patients for iron deficiency, even though they are neither sensitive nor specific (Drakesmith and Patience 2012). Haemoglobin concentrations lower than $13 ; \mathrm{g} / \mathrm{dL}$ in men and $12 \mathrm{~g} / \mathrm{dL}$ in women indicate the presence of IDA (Drakesmith and Patience 2012). Normal hematocrit values, which are generally three times higher than haemoglobin levels, are approximately $13.7 \%$ to $16.7 \%$ in males and $12 \%$ to $14.7 \%$ in females. (Conrad ME 2006).

\section{CAUSES OF IRON DEFICIENCY}

Isolated iron deficiency is uncommon in the Western region of Africa. Because iron deficiency is associated with poor diet, mal absorptive disorders, and blood Loss, people with iron deficiency usually have other nutrient deficiencies (Aggetet. al., 2010). The World Health Organization (WHO) estimates that approximately half of the 1.62 billion cases of anaemia worldwide are due to iron deficiency (WHO 2008) In developing countries, iron deficiency often results from enteropathies and blood loss associated with gastrointestinal parasites (Agget et. al., 2010).

Iron depletion and deficiency progresses through several stages (WHO 2012):

1. Mild deficiency or storage iron depletion: Serum ferritin concentrations and levels of iron in bone marrow decrease.

2. Marginal deficiency, mild functional deficiency, or iron-deficient erythropoiesis (erythrocyte production): Iron stores are depleted, iron supply to erythropoietic cells and transferrin saturation decline, but haemoglobin levels are usually within the normal range. In addition, plasma iron levels decline and plasma transferring concentrations (measured by plasma total iron-binding capacity) rise, resulting in decreased transferrin saturation. Serum transferrin receptor concentrations also increase.

3. IDA: Iron stores are exhausted; hematocrit and levels of haemoglobin decline; and the resulting microcytic, hypochromic anaemia is characterized by small red blood cells with low haemoglobin concentrations. 
IDA is defined as a haemoglobin level that is lower than two standard deviations from the mean distribution in a healthy population of the same gender and age living at the same altitude (WHO 2001) At sea level, haemoglobin concentrations lower than 11 to $12 \mathrm{~g} / \mathrm{dL}$ in children younger than $12,12 \mathrm{~g} / \mathrm{dL}$ in adolescents and women, and $13 \mathrm{~g} / \mathrm{dL}$ in men indicate the presence of IDA (Agget et. al., 2010). In 2002, the WHO characterized IDA as one of the 10 leading risk factors for disease around the world (WHO 2002). Although iron deficiency is the most common cause of anaemia, deficiencies of other micronutrients (such as folate and vitamin B12) and other factors (such as chronic infection and inflammation) can cause different forms of anaemia or contribute to their severity.

The functional deficits associated with anaemia include gastrointestinal disturbances and impaired cognitive function, immune function, exercise or work performance, and body temperature regulation (Clark 2008). In infants and children, IDA can result in psychomotor and cognitive abnormalities that, without treatment, can lead to learning difficulties (Agget et. al., 2010 and Clark 2008). Some evidence indicates that the effects of deficiencies early in life persist through adulthood (Agget et. al., 2010). Because iron deficiency is often accompanied by deficiencies of other nutrients, the signs and symptoms of iron deficiency can be difficult to isolate (Agget et. al., 2010).

The causes of iron deficiency are usually inadequate intake of iron from ignorance of what foods to choose from sheer lack of food altogether of from high consumption of iron- poor foods. In the developing world for instance, it is believed that children should not take much meat or beef which is a major source of iron so as not to indulge in stealing. Some believe that giving beef to children can lead to parasitic infections.

Other Causes of Iron Deficiency are:

- When the iron in diet in a form that cannot be absorbed, e.g. diet that contains phytic acid which inhibits the absorption of non heme iron. Examples are found in grains.

- Increase loss of iron due to chronic blood loss as occurred in severe hookworm infection.

- Mal-absorption of iron as in intestinal mal-absorptive disease e.g. acute post infective mal-absorption.

- Increase demand for iron as occurred in early years of life and during pregnancy.

\section{IRON'S ROLES IN CHILDREN'S ACADEMIC DEVELOPMENT}

According to Pollitt (1997) during the first two years of life, complex post-natal neural changes occur in the human brain. Iron deficiency during this time can lead to withdrawal, inability to respond to the environment, poor motor function and poor mental function.

Therefore, increasing iron intake has been reported to improve mental development in school children, cognitive function, long term memory, and attentiveness. It should be noted according to Ojofehintimi (2007) that iron molecules in the body are present in different types such as heme protein(haemoglobin, myoglobin) enzymes heme (cytochromes, catalase), enzymes, nonheme (iron-sulphur and metaloproteins) transport and storage proteins (tranferirin, ferritin, nemosidenin). 
The major functions of iron are:

- Helps in the building of red blood cells

- It involves in the oxidation and reduction reactions

- It is essential part of haemoglobin that carries oxygen from the lungs to all cells in the body.

- Iron forms part of enzymes which helps in breaking down fats, carbohydrates and proteins.

- It helps in the conversion of hydrogen peroxide to oxygen and water.

- Iron's presence in the bone marrow help red cells to develop.

- It helps in the electron transport (cytochromes) Ojofehintimi (2007)

\section{EFFECT OF IRON DEFICIENCY ON CHILDREN'S ACADEMIC DEVELOPMENT}

The World Health Organization (WHO) considers iron deficiency the number one nutritional disorder in the world (Stotzfus, 2001). As many as $80 \%$ of the world's population may be iron deficient while $30 \%$ may have iron deficiency anaemia. (Hurrel, 2004). Iron deficiency develops and usually begins with negative iron balance, when iron intake does not meet the daily need for dietary iron. This negative balance initially depletes the storage form of iron while the blood haemoglobin level, a marker of iron status remains normal. Iron deficiency anaemia is an advanced stage of iron depletion. It occurs when storage sites of iron are deficient and blood levels of iron cannot meet daily needs. Blood haemoglobin levels are below normal with iron deficiency anaemia.

Van Stuijvenberg et. al., (1997) stated that Vitamin A helps mobilize iron from its storage sites, so a deficiency of vitamin A limits the body's ability to use stored iron. This results in an "apparent" iron deficiency because haemoglobin levels are low even though the body can maintain normal amounts of stored iron. Kolsteren et. al., (1999) added that this problem is seen in developing countries where Vitamin A deficiency often occurs.

Chronic mala-absorption can contribute to iron depletion and deficiency by limiting dietary iron absorption or by contributing to intestinal blood loss. Most iron is absorbed in the small intestines. Gastro intestinal disorders that result in inflammation of the small intestine may result in diarrhoea, poor absorption of dietary iron and iron depletion (Annibale et. al., 2001).

Signs of iron deficiency anaemia include:

- Feeling tired and weak

- Ill looking nails

- Decreased work and school performance

- Slow cognitive and social development during childhood

- Difficulty maintaining body which increases susceptibility to infection. 
- Glossitis (an inflamed tongue)

(Haas, 2001) (Bhaskaran, 2001)

Eating non-nutritive substances such as dirt and clay, often referred to as Pica or geophagia, is sometimes seen in person with iron deficiency. There is disagreement about the cause of this association. Some researchers believe that these eating abnormalities may be as a result of iron deficiency. Other researchers believe that iron deficiency may somehow increase the likelihood of these eating problems. (Rose et. al., 2000), Singhi S. 2003).

\section{IRON DEFICIENCY AND ANAEMIA}

The distinction between iron deficiency and anaemia is important (according to Hoffman et.al., 2000). They often go hand in hand, but people can be anaemic without being iron deficient and iron deficiency without anaemic. Anaemia according to Abramson (1999) is a symptom of a wide variety of disorders, some unrelated to nutrition, and some related to nutrient other than iron, such as foliate and vitamin B12. In iron deficiency anaemia, new red blood cells are smaller and lighter red than normal. The depleted cells cannot carry enough oxygen from the lungs to the tissues, so energy metabolism in all the cells is hindered and the entire body feels the effect.

Anaemia is a clinical sign of severe iron deficiency. Other classic symptoms include fatigue weakness, headaches, apathy, pallor or poor tolerance to cold. One way the body accelerates heat production when the environmental temperature falls involves the neurotransmitter norepinephrine and the thyroid hormones which speed up the metabolic rate. Iron deficiency impairs temperature regulator in both animals and human beings, probably by interfering with the normal production of these compounds (Abramson, 1999).

Less severe iron deficiency produces symptoms too long before the red blood cells are affected the anaemia is diagnosed, a developing iron deficiency affects behaviour. Even at slightly lowered iron levels, the complete oxidation of pyruvate is impaired, reducing physical work capacity and productivity. Children deprived of iron become irritable, restless and unable to pay attention. These symptoms are among the first to appear when the body's iron level begins to fall and among the first to disappear when iron status is restored, (Bolt et. al, 1999).

\section{IRON DEFICIENCY AND PICA}

A curious symptom sometimes seen in iron deficient individuals is an appetite for ice, clay or other non-nutritious substances. Some people have been known to eat as many as eight trays of ice in a day. For example this behaviour known as pica has been observed for years especially in women and children of low-income groups who are deficient in iron. After iron is given pica clears up dramatically within days, long before the red blood cells responds (Spivak, 2001). 
Generally, development is measure in the following areas: fine motor, gross motor, cognitive, self-help, social emotional, expressive and receptive language. But for the purpose of this study, children's cognitive development will be considered.

\section{PROBLEM STATEMENT}

Recent researches conducted in Lagos State have shown that children within the age of 8-10years have a high prevalence of iron deficiency. Thus according to Hurrel (1997) this vital element is essential for children's cognition because it enhances behavioural and intellectual performance and promotes the body's resistance to infections. He further added that the risk of iron deficiency increases during period of rapid growth notably among these age groups. Therefore, the aim of this research is to assess the anthropometric and iron status of pupils within this age group in Shomolu Local Government Area of Lagos State. The result will be given effective solution, should the respondents be found lacking in iron.

\section{JUSTIFICATION OF THE STUDY}

This research will give a better understanding of the Anthropometric and iron status of schoolchildren in Somolu Local Government Area in Lagos State in Nigeria. This will enable both the State and Federal Government to know their health Status and how to address it. It will also help subsequent researches.

In view of the high prevalence of iron deficiency anaemia among under five(5) children in Nigeria, this study will further provide information on the association between iron status and anthropometry among school children.

Children, particularly those within the age of 8-10 years have important needs for iron. This is because the risk of iron deficiency increases during periods of rapid growth notably among this age group.

Iron is a vital element essential for children's cognition because it enhances behavioural and intellectual performance and promotes the body's resistance to infections.

\section{BROAD OBJECTIVE:}

The broad objective is to assess the anthropometric and iron status of school children in Somolu Local Government area.

\section{SPECIFIC OBJECTIVES:}

1. To determine the haemoglobin, PCV and serum ferritin status of school children.

2. To assess the anthropometric status of school children.

3. To assess the pattern of consumption of foods rich in iron among respondents. 
4. To determine the relationship between iron status, anthropometric and socio economic characteristics of school children.

\section{RESEARCH QUESTIONS}

1. What is the haemoglobin, PCV and serum ferritin level of the pupils under study?

2. What is the nutritional status of the children under study from the anthropometric measurement taken?

3. What is the level of iron intake from food frequency questionnaire?

4. What is the relationship between iron status, anthropometric and socioeconomic characteristics of school children.

\section{METHODOLOGY}

\section{Study Design}

This is a cross sectional and descriptive writing. Both survey and laboratory analysis from the selected few schools are taken to the laboratory for analysis.

\section{Study Population}

The study population is school age children between the ages of $8-10$ years age group in the selected schools of that Local Government Area.

\section{Sample Size}

The sample size is 140 school children who were purposively selected from the 3 schools. A purposive sampling was used to select 91 respondents for biochemical analyses out of the 140samples that were intended to be used.

\section{Ethical Approval}

Ethical approval was obtained from the Ethical Committee of the Lagos State University Teaching Hospital in conjunction with the State Ministry of Health, Alausa, Ikeja Lagos. Also consent was obtained from State Universal Primary Education Board (SUPEB) and those wards that will be used for the study.

Prior to the commencement of the field work, a written consent was taken from the parents of the subjects to be used.

\section{Instrument of Data Collection}

A structured Questionnaire was used for the data collection. Medical personnel and a trained certified technologist was employed for biochemical assessment of the children's level of serum ferritin. Trained research assistants were also used for data collection. The questionnaire used for data collection was sectionalized as follows: 


\footnotetext{
i. Personal Data

ii. Socio Economic Background

iii. Anthropometric measurements (weight, height and MUAC)

iv. Data on dietary source of iron intake was collected using Food Frequency Questionnaire (FFQ).

v. Then Biochemical Data was collected from 91 respondents whose parents gave their consent. PCV, Hb. and Ferritin were analysed.
}

\section{RESULTS}

\section{Discussion and Interpretation of Tables and Figures}

Table 3 below presents percentage distribution of respondents' Socio Economic variables. From the table $3,88(62.9 \%)$ of the pupils were male while, $52(37.1 \%)$ were female. Also from the table 3, $71(50.7 \%)$ of the pupils were between ages 7-9 years, $69(49.3 \%)$ were between ages 10-12 years. Distribution of pupils genotype revealed that $89(63.6 \%)$ were AA, $30(21.4 \%)$ were AS, $7(5.0 \%)$ were AC. $9(6.4 \%)$ were SS and $5(3.6 \%)$ were SC.

Table 3: Socio Economic Variable of Respondents - Gender, Age and Genotype of Pupils

\begin{tabular}{llll}
\hline & Variable & Frequency & Percentage \\
\hline Gender & Male & 88 & 62.9 \\
& Female & 52 & 37.1 \\
& Total & $\mathbf{1 4 0}$ & $\mathbf{1 0 0 . 0}$ \\
Age & 7-9 years & 71 & 50.7 \\
& & & \\
& 10- 12 years & 69 & 49.3 \\
& Total & $\mathbf{1 4 0}$ & $\mathbf{1 0 0 . 0}$ \\
AA & 89 & 63.6 \\
AS & 30 & 21.4 \\
AC & 7 & 5.0 \\
& SS & 9 & 6.4 \\
& SC & 5 & 3.6 \\
Total & $\mathbf{1 4 0}$ & $\mathbf{1 0 0 . 0}$ \\
\hline
\end{tabular}

From figure 1 below, $12(8.6 \%)$ of the male guidance and $8(5.7 \%)$ of the female guidance did not respond, $3(2.1 \%)$ of male guidance and $4(2.9 \%)$ female guidance had no formal education, $6(4.3 \%)$ of 
the male and $7(5.0 \%)$ of female guidance had primary education $26(18.6 \%)$ of male and $38(27.1 \%)$ of female guidance had secondary education and $93(66.4 \%)$ of male and $38(59.3 \%)$ of female guidance had tertiary education. This implies that majority of the respondents came from educated homes.

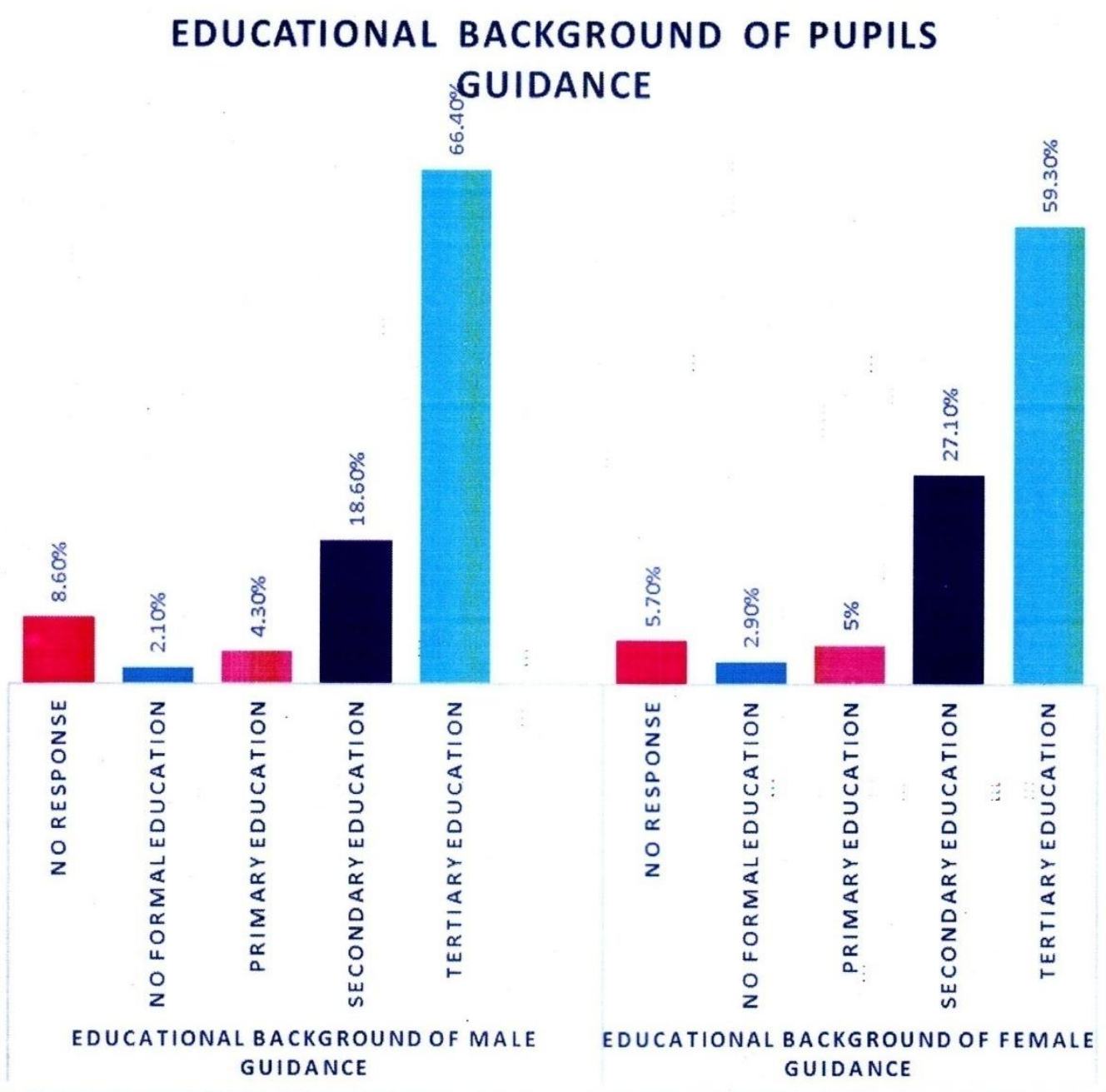

Figure 1: Socio Economic Variable of Respondents - Educational background of pupils' guidance

From figure 2 below, $3(2.1 \%)$ of the pupils lived in a room apartment, $42(30.0 \%)$ lived in a room and a parlour, $78(55.7 \%)$ lived in a block of flats, 14 (10.0\%) lived in a duplex and $3(2.1 \%)$ lived in "Self Contained" types of houses. $1(0.7 \%)$ did not respond to the type of the house they lived in, $105(75.0 \%)$ lived in a rented apartment and 34 (24.3\%) lived in an inherited or built house. 


\section{TYPE AND OWNER OF HOUSING}

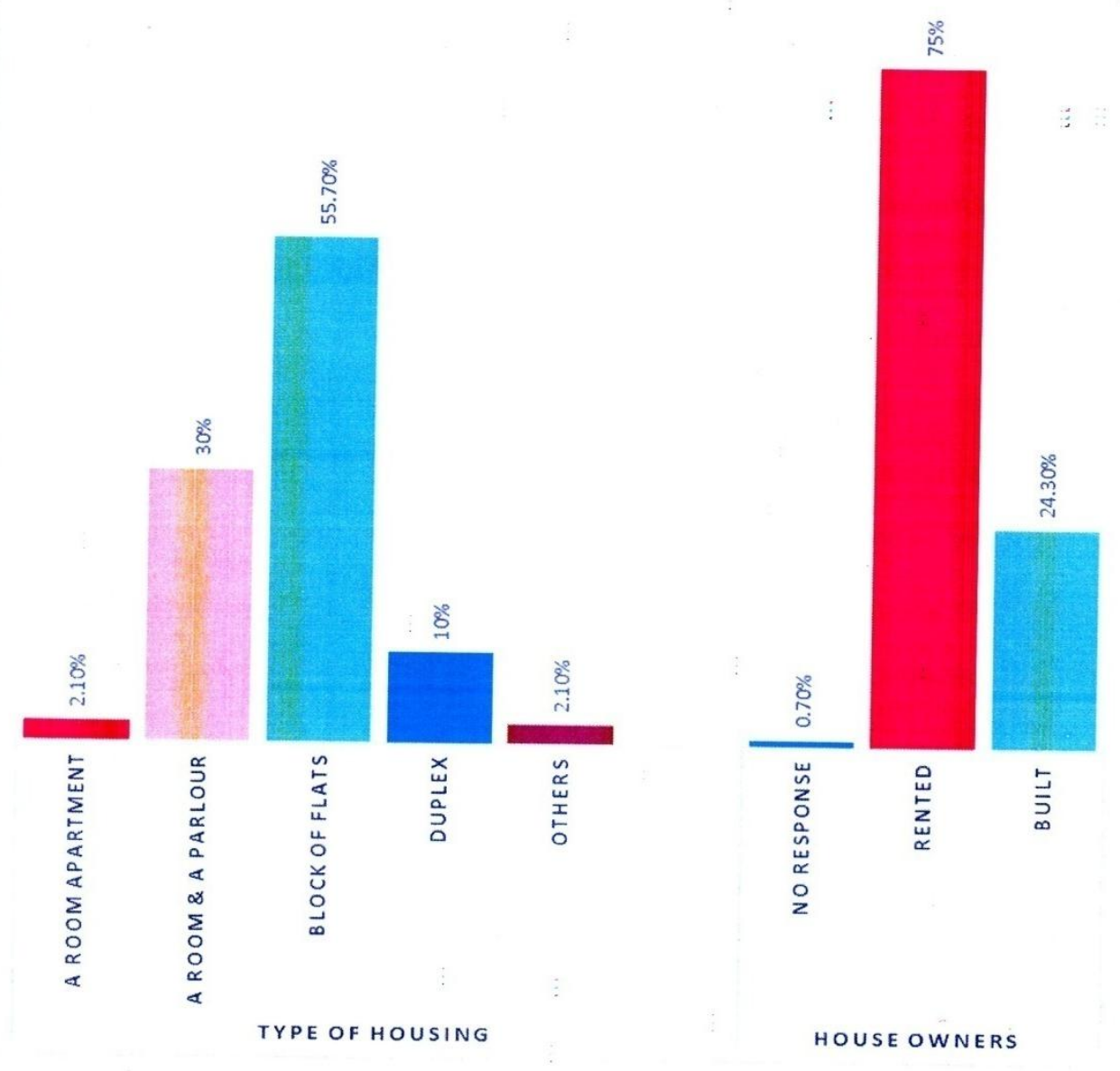

Figure 2: Socio Economic Variable of Respondents - Type and Owner of Housing of

Pupil's Guidance

From table 4 below, $82(58.6 \%)$ of the pupils had between 1-3 children in their family, 56(40.0\%) had between 4-6 children in their family and $2(1.4 \%)$ had 7 and above children in their family.

Distribution of respondents by position in the family, 5 (3.6\%) did not respond, 56 (40.0\%) were first position in the family, $50(35.7 \%)$ were second in the family, $17(12.1 \%)$ were third, $6(4.3 \%)$ were fourth in the family, $5(3.6 \%)$ were fifth position in the family and $10.7 \%$ ) was sixth position in the family. Out of the respondents, $2(1.4 \%)$ source of breakfast were home prepared, $5(3.6 \%)$ of the pupils breakfast 
were purchased at horns, $130(92.9 \%)$ source of breakfast were purchased at school and $3(2.1 \%)$ source of breakfast were purchased on the streets. This implies that despite the majority of the respondents came from educated homes, the major source of their breakfast was purchased from the school.

Table 4: Socio Economic Variable of Respondents - Number of Children in the family, position of pupils in the family and Sources of Breakfast

\begin{tabular}{llll}
\hline & Variable & Frequency & Percentage \\
\hline Number of Children in & 1 - 3Children & 82 & 58.57 \\
the family & 4-6 Children & 56 & 40.0 \\
& 7 and above & 2 & 1.4 \\
& Total & $\mathbf{1 4 0}$ & $\mathbf{1 0 0 . 0}$ \\
Position in the Family & No response & 5 & 3.6 \\
& 1 & 56 & 40.0 \\
& 2 & 50 & 35.7 \\
& 3 & 17 & 12.1 \\
& 4 & 6 & 4.3 \\
& 5 & 5 & 3.6 \\
& 6 & 1 & 0.7 \\
& Total & $\mathbf{1 4 0}$ & $\mathbf{1 0 0}$ \\
& Home Prepared & 2 & 1.4 \\
& Purchased at home & 5 & 3.6 \\
& Purchased at school & 130 & 92.9 \\
& Purchased on the street & 3 & 2.1 \\
& Total & $\mathbf{1 4 0}$ & $\mathbf{1 0 0}$
\end{tabular}

Table 5 below showed that $187 \%$ of the respondents were iron deficient because their value were less than the normal ferritin level $(<15 \mathrm{ng} / \mathrm{ml})$. $66 \%$ of the respondents had a normal ferritin status (15-100ng/ml) while $14.4 \%$ of the respondents had abnormal ferritin status in that their status was above normal i.e. $>100 \mathrm{ng} / \mathrm{ml}$. However, $57.1 \%$ and $58 \%$ of the respondents were anaemic or were suffering from Iron deficiency anaemia.

This result showed that there must have been an underlying ailment in the respondents under study since more than half percentage of the respondents had a normal ferritin status and at the same time their $\mathrm{Hb}$ and PCV status revealed they were anaemic. This result agreed with Brabin 1992 which stated that once an infection like malaria parasite is present, the parasite destroy the red blood cell which reduces the 
percentage of the Red Blood Cell count and once the Red Blood Cell are broken, ferritin is released into the blood. This implied that malaria parasites are likely to be present in these respondents since they lived where malaria is endemic as most houses in the area of study location operate open drainage which enhances the breeding of mosquito parasites.

Also, since $75 \%$ of the respondents live in rented apartments, the environment may not be hygienic enough which is also a predisposing factor in the infestation of worm parasites or other infections such as salmonella typhii in respondents under study. This could also affect the ferritin status of the respondents.

Table 5: The Hermatological Parameters: Distribution of Respondents by Haemoglobin, PCV and Serum Ferritin Level

\begin{tabular}{|c|c|c|c|c|c|c|c|}
\hline \multirow[t]{2}{*}{ Parameter } & \multirow[t]{2}{*}{ Gender } & \multicolumn{2}{|l|}{$\begin{array}{l}<\text { Normal } \\
<15 \mathrm{ng} / \mathrm{ml}\end{array}$} & $\begin{array}{l}\text { Normal } \\
15-100 \mathrm{ng} / \mathrm{ml}\end{array}$ & \multicolumn{3}{|c|}{$\begin{array}{l}\text { Abnormal } \\
>100 \mathrm{ng} / \mathrm{ml}\end{array}$} \\
\hline & & Freq & $\%$ & Freq & $\%$ & Freq & $\%$ \\
\hline & & & & 29 & 31.8 & 5 & 5.5 \\
\hline & Male & 7 & 7.8 & & & & \\
\hline \multirow[t]{4}{*}{ Ferritin } & Female & 10 & 10.9 & 32 & 35.1 & 8 & 8.9 \\
\hline & Total & 17 & 18.7 & 61 & 66.9 & 13 & 14.4 \\
\hline & \multicolumn{3}{|c|}{ Normal $(100-115 g / \mathrm{I})$} & \multicolumn{4}{|c|}{ Low $(<100 \mathrm{~g} / \mathrm{I})$} \\
\hline & & Freq & $\%$ & & Freq & $\%$ & \\
\hline \multirow[t]{5}{*}{ Hb. } & Male & 15 & 16.5 & & 22 & 24.1 & \\
\hline & Female & 24 & 26.4 & & 30 & 33.0 & \\
\hline & Total & 39 & 42.9 & & 52 & 57.1 & \\
\hline & \multicolumn{3}{|c|}{ Normal $(100-115 \mathrm{~g} / \mathrm{I})$} & \multicolumn{4}{|c|}{ Low $(<100 \mathrm{~g} / \mathrm{I})$} \\
\hline & & Freq & $\%$ & & Freq & $\%$ & \\
\hline \multirow[t]{3}{*}{ PVC } & Male & 17 & 18.7 & & 22 & 24.2 & \\
\hline & Female & 23 & 25.3 & & 29 & 31.8 & \\
\hline & Total & 40 & 44.0 & & 51 & $\mathbf{5 8 . 0}$ & \\
\hline
\end{tabular}

Table 7 showed that $27 \%$ of the male and $27.3 \%$ of the female respondents were underweight because their weight for age values was less than -2SD from median of WHO growth reference. $58.7 \%$ of the male respondents and $72.7 \%$ of the female respondents had normal weight. Weight values fell within the range of $(-2$ to $+2 \mathrm{SD})$ median of $\mathrm{WHO}$ growth reference. While only $14.3 \%$ of the male respondents were mildly overweight. 
Stunting was well pronounced in the female respondents compared to the male respondents because $18.2 \%$ of the female respondents and $12.7 \%$ of the male respondents were stunted in that their height for age value was <2SD from the median of WHO growth reference. This result agreed with (de Onis et. al. 2007) who noted that a prevalence of stunting in girls compared to boys was found among school age children.

$84.1 \%$ of the male respondents and $75.3 \%$ of the female respondents had a normal height; their height for age values fell within the median range (-2SD to $+2 \mathrm{SD}$ ) of WHO growth reference. $3.2 \%$ of the male and $6.5 \%$ of the female respondents were above the average height in that their height for age value was greater than the median of WHO growth reference $>+2 \mathrm{SD}$.

$14.3 \%$ of the male and $15.6 \%$ of the female respondents were wasted in that their BMI for age was less than -2SD from the median or 5th percentile of WHO growth reference. Gibson (2005), WHO (2001)

Table 7: Distribution of Underweight, Stunting and Wasting among males and females in Somolu LGA

\begin{tabular}{|c|c|c|c|}
\hline Variable & Boys & N (\%) & Girls \\
\hline Weight-for-age (Underweight) & & & \\
\hline$<-2 S D$ & $\mathbf{1 7}(\mathbf{2 7 . 0})$ & & $\mathbf{2 1}(\mathbf{2 7 . 3 )}$ \\
\hline-2 to +2 SD & $37(58.7)$ & & $56(72.7)$ \\
\hline$>+2 S D$ & $9(14.3)$ & & $-(-)$ \\
\hline Total & 63 & & 77 \\
\hline Height-for-age-(stunting) & & & $\mathbf{1 4}(\mathbf{1 8 . 2})$ \\
\hline$<-2$ SD & $\mathbf{8 ( 1 2 . 7 )}$ & & $58(75.3)$ \\
\hline-2 to $+2 S D$ & $53(84.1)$ & & $5(6.5)$ \\
\hline$>+2 S D$ & $2(3.2)$ & & 77 \\
\hline Total & 63 & & $\mathbf{1 2 ( 1 5 . 6 )}$ \\
\hline BMI-for-age (Wasting) & & & $52(67.5)$ \\
\hline$<-2 S D$ & $\mathbf{9 ( 1 4 . 3 )}$ & & $13(16.9)$ \\
\hline-2 to + 2SD & $50(79.4)$ & & 77 \\
\hline$>+2 S D$ & $4(6.3)$ & & \\
\hline Total & 63 & & \\
\hline
\end{tabular}

Table 8 shows patterns of Dietary Iron intake among the school age respondents. However, according to Cook et al. (1996), diet in tropical countries are often high in substances which inhibit the absorption of non-haem iron e.g. phytic acid in grain, tannin in coffee but ascorbic acid in the diet helps to absorb the non-haem iron.

$80.71 \%$ and $75.71 \%$ of the respondents had a low consumption of haem iron (from animal origin) $60.71 \%$ of the respondents frequently consume Garri which contained. little or no iron. $86.43 \%$ of the 
respondents consumed beans only once or twice a week which is a non-haem iron (from plant origin). $80 \%$ of the respondents had a poor consumption of orange and other fruits. It was only consumed once or twice in a week, which could have enhanced the absorption of the non-haem iron in other foods. 50\% of the respondents consumed Indomie frequently. $45.71 \%$ of the respondents had a high consumption of beverages which contained tannin that could inhibit the absorption of iron in their diet.

The results from this table agreed with Tatala et. al. (1998) that poor diet quality and low dietary iron bio availability are the principal factors that contribute to the increase of iron deficiency.

Table 8: Pattern of Dietary Iron Intake

\begin{tabular}{|c|c|c|c|c|c|c|c|}
\hline \multirow[t]{2}{*}{ Food items } & \multirow{4}{*}{ 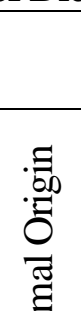 } & \multicolumn{2}{|c|}{$\begin{array}{l}\text { Low (1 to } 2 \text { days per } \\
\text { week) }\end{array}$} & \multicolumn{2}{|c|}{$\begin{array}{l}\text { Moderate per (3 to } 4 \\
\text { days week) }\end{array}$} & \multicolumn{2}{|c|}{$\begin{array}{l}\text { High (5 to } 7 \text { days per } \\
\text { week) }\end{array}$} \\
\hline & & Freq & Per & Freq & Per & Freq & Per \\
\hline Beef & & 113 & $80.71 \%$ & 14 & $10.00 \%$ & 13 & $9.83 \%$ \\
\hline Fish & & 106 & $75.71 \%$ & 21 & $15.00 \%$ & 15 & $10.70 \%$ \\
\hline Chicken & 寻 & 115 & $82.14 \%$ & 8 & 5.71 & 15 & $10.70 \%$ \\
\hline Turkey & & 122 & $87.14 \%$ & 6 & $4.29 \%$ & 5 & $3.57 \%$ \\
\hline Evaporated milk & & 101 & $72.14 \%$ & 14 & $10.00 \%$ & 10 & $7.14 \%$ \\
\hline Powdered milk & & 57 & $40.71 \%$ & 46 & $32.86 \%$ & 30 & $21.43 \%$ \\
\hline Eggs & & 138 & $98.00 \%$ & 5 & $3.57 \%$ & 0 & $0.00 \%$ \\
\hline Garri & & 4 & $2.86 \%$ & 53 & $37.86 \%$ & 85 & 60.71 \\
\hline Beans & 的 & 121 & $86.43 \%$ & 14 & $10.00 \%$ & 7 & $5 \%$ \\
\hline Vegetables & 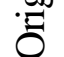 & 98 & $70.00 \%$ & 9 & $6.43 \%$ & 33 & $23.57 \%$ \\
\hline Banana & $=$ & 118 & $84.29 \%$ & 3 & $2.14 \%$ & 12 & $8.57 \%$ \\
\hline Orange & $\frac{\pi}{2}$ & 112 & $80.00 \%$ & 11 & $7.86 \%$ & 15 & $10.71 \%$ \\
\hline Apple & & 115 & $82.14 \%$ & 6 & $4.29 \%$ & 8 & $5.71 \%$ \\
\hline Mango & & 84 & $60.00 \%$ & 6 & $4.29 \%$ & 5 & $3.57 \%$ \\
\hline Tangerine & $\cong$ & 98 & $70.00 \%$ & 11 & $7.86 \%$ & 4 & $2.86 \%$ \\
\hline Gala & .50 & 47 & $33.57 \%$ & 70 & $50.00 \%$ & 22 & $15.71 \%$ \\
\hline Flour & $\underline{0}$ & 88 & $62.86 \%$ & 17 & $12.14 \%$ & 9 & $6.43 \%$ \\
\hline Semovita & 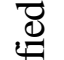 & 97 & $69.29 \%$ & 17 & $12.14 \%$ & 8 & $5.71 \%$ \\
\hline Indomie & 㺃 & 28 & $20.00 \%$ & 44 & $31.43 \%$ & 70 & $50.00 \%$ \\
\hline Beverages & I & 34 & $24.29 \%$ & 44 & $31.43 \%$ & 64 & $45.71 \%$ \\
\hline
\end{tabular}

Results in Table 9 showed that there is a significant relationship between parental income and children iron status. This implies that the parental income of respondents determines their ferritin status. This study agreed with Onimawo (2006) who affirmed from his study that school children from a high or average socioeconomic class were found to have a good iron status while children from low socioeconomic class were found to have a poor iron status. This implied that low standard of living restricted access to food, lack of knowledge for good dietary practices and personal hygiene contribute to a high occurrence of iron deficiency. 
Table 9: Relationship between iron status and Socio Economic characteristics (Parental Income)

\begin{tabular}{lcccccccc}
\multicolumn{2}{c}{ Variables } & Mean & Std Dev & N & Df & r-cal & p-value & Remark \\
\hline $\begin{array}{l}\text { Socio Economic } \\
\text { (Parental Income) }\end{array}$ & characteristics & 35.79 & 5.8995 & 140 & 138 & 0.24 & $0.004^{*}$ & Significant \\
& & & & & & &
\end{tabular}

Children iron status

$79.22 \quad 17.1982$

From table 10 below, there was a correlation between respondents Haemoglobin and BMI, a negative correlation between Haemoglobin and respondents height. This implies that the presence or deficiency of haemoglobin affects school children development. This agrees with a study carried out by Onimawo (2013) that stunting and wasting were identified in children with iron deficiency anaemia.

Table 10: Relationship between Haemoglobin and anthropometric characteristics of children according to gender

\begin{tabular}{lccccc}
\hline Variable & & $\begin{array}{c}\text { Male }(\mathbf{N}=\mathbf{6 4}) \\
(\mathbf{z}-\mathbf{s c o r e})\end{array}$ & P value & $\begin{array}{c}\text { Female }(\mathbf{N}=\mathbf{7 6}) \\
\text { (z-score) }\end{array}$ & P value \\
\hline Haemoglobin & Weight & -.023 & .859 & -.134 & .249 \\
& Height & .143 & .261 & $\mathbf{- . 3 1 8 *}$ & $\mathbf{. 0 0 5}$ \\
& MUAC & .033 & .794 & -.151 & .192 \\
& BMI & $\mathbf{. 2 8 9 *}$ & $\mathbf{. 0 2 0}$ & .077 & .506 \\
\hline
\end{tabular}

Haemoglobin was positively correlated with male pupils BMI $(\mathrm{r}=0.289, \mathrm{p}<0.05)$ and it was negatively correlated with female pupils height $(\mathrm{r}--0.318, \mathrm{p}<0.05)$. No correlation was observed among other variables.

Table 11: Relationship between PCV and anthropometric characteristics of children according to gender.

\begin{tabular}{lccccc}
\hline Variable & & $\begin{array}{c}\text { Male }(\mathbf{N}=64) \\
(\mathbf{z}-\mathbf{6 c o r e})\end{array}$ & P value & $\begin{array}{c}\text { Female }(\mathbf{N}=\mathbf{7 6}) \\
(\mathbf{z}-\mathbf{s c o r e})\end{array}$ & P value \\
\hline PCV & $\begin{array}{l}\text { Weight } \\
\text { Height }\end{array}$ & .019 & .884 & .198 & .087 \\
& & -.034 & .787 & .075 & .517 \\
& MUAC & 034 & .790 & $.225^{* *}$ & .051 \\
& BMI & $\mathbf{2 0 9 * *}$ & $\mathbf{. 0 2 8}$ & -.065 & .579 \\
\hline
\end{tabular}


PCV was positively correlated with MUAC of the female pupils $(\mathrm{r}=0.225, \mathrm{p}<0.05)$ and $(\mathrm{r} 0.209, \mathrm{p}<$ 0.05) BMI for male pupils.

From Table 12 below positive correlation exist between Ferritin and genotype of both male and female ( $\mathrm{r}$ $=0.276, \mathrm{p}<0.05),(\mathrm{r}=0.341, \mathrm{p}<0.05)$ and there was a positive relationship between ferritin and food intake pattern of female pupils $(r=0.288, p<0.05)$. This implies that the genotype of school children affects their ferritin status. Also the food intake pattern of school children determines their iron status. It also showed that the ferritin status of the subjects under study had nothing to do with their anthropometric status since there was no correlation between the ferritin and the anthropometry of the children of both gender.

Table 12: Relationship between Ferritin and anthropometric characteristics of children according to gender

\begin{tabular}{|c|c|c|c|c|c|}
\hline Variable & & $\begin{array}{c}\text { Male }(\mathbf{N}=64) \\
\text { (z-score) }\end{array}$ & P value & $\begin{array}{c}\text { Female }(\mathrm{N}=76) \\
(\mathrm{z} \text {-score })\end{array}$ & P value \\
\hline \multirow[t]{8}{*}{ Ferritin } & Weight & .183 & .149 & .029 & .805 \\
\hline & Height & -.138 & .277 & .102 & .382 \\
\hline & MUAC & .199 & .116 & .001 & .990 \\
\hline & BMI & -.034 & .792 & -.179 & .121 \\
\hline & Haemoglobin & -.108 & .397 & .087 & .456 \\
\hline & PCV & -.224 & .075 & -.156 & .178 \\
\hline & Genotype & $.276^{* *}$ & .027 & $.341 * *$ & .003 \\
\hline & Food intake pattern & .056 & .658 & $.288 * *$ & .012 \\
\hline
\end{tabular}

A positive correlation exists between Ferritin and genotype of both male and female $(r=0.276, p<0.05)$, $(\mathrm{r}=0.341, \mathrm{p}<0.05)$ and there was a negative relationship between ferritin and food intake pattern of female respondents $(r=0.288, p<0.05)$. There was no correlation between ferritin and anthropometric features of respondents in both gender. 
Table 13: Cross tabulation between ferritin status and genotype

\begin{tabular}{ccccc}
\hline Genotype & \multicolumn{4}{c}{ Ferritin } \\
\hline & Normal level $(15-100 \mathrm{ng} / \mathrm{ml})$ & \multicolumn{2}{c}{ High level $(>100 \mathrm{ng} / \mathrm{ml})$} \\
\hline AA & Frequency & Percentage & Frequency & Percentage \\
AS & 83 & $90.2 \%$ & 9 & $9.8 \%$ \\
SS & 21 & $77.8 \%$ & 6 & $22.2 \%$ \\
AC & 3 & $33.3 \%$ & 6 & $\mathbf{6 6 . 7 \%}$ \\
SC & 1 & $14.3 \%$ & 6 & $\mathbf{8 5 . 7 \%}$ \\
Total & 2 & $40.0 \%$ & 3 & $\mathbf{6 0 . 0 \%}$ \\
\hline
\end{tabular}

A high level of ferritin was identified in SS, AC and SC genotype blood group. The values of these genotype groups were greater than normal reference values $(15-100 \mathrm{ng} / \mathrm{ml})$. This study agreed with Adelakun et. al. (1990). Who discovered an excess iron stores in subjects with SC, SS and AC blood genotyped group.

Table 14: Relationship between ferritin and genotype

\begin{tabular}{lcccccc}
\hline Variables & Mean & Std Dev & N & r-cal & p-value & Remark \\
\hline Ferritin & 13.20 & 5.6362 & & & & \\
& & & & & & \\
& & & 140 & 0.563 & 0.000 & significant
\end{tabular}

Genotype

$1.61 \quad 1.049$

There was a positive relationship between respondents' ferritin status and genotype which implies that the respondents' genotype determines their ferritin status. And this was revealed in the results because respondents with AC, SS and SC genotyped blood group were found to have their ferritin status $>100 \mathrm{ng} / \mathrm{ml}$ which means they had abnormal ferritin status in that their ferritin level was greater than the normal reference value $(15-100 \mathrm{ng} / \mathrm{ml})$. Meanwhile it was not so in other blood genotype respondents, in that excessive breakdown of haemoglobin as a result of excess iron stores in the reticulo endothelial cells in the subjects of the AC, SS and SC blood genotype group was discovered. 


\section{CONCLUSIONS AND RECOMMENDATIONS}

\section{Conclusions}

- The result of this study established that $66.9 \%$ of the respondents had a normal ferritin status while $57.2 \%$ of the respondents were iron deficient in that their PCV and $\mathrm{Hb}$ were low which implies there was an underlying ailment in the subjects under study.

- The low haemoglobin and PCV status of the respondents affect their growth or physical development.

- The socio economic status or parental incomes of the respondents have: a positive influence on their iron status.

- The respondents though from educated homes had a poor dietary habit and low dietary iron bioavailability which are a principal factor that contribute to the increase in iron deficiency.

- The genotype of the respondents determines their iron status.

\section{Recommendations}

- The research gives an insight and a better understanding of the Anthropometric andiron status of school children in the used Location. State and FG to institute programmes to improve the iron status of school children.

- Gari, Indomies and Beverages producers should richly fortify their products with iron, since a high percentage of the respondents take these foods more frequently.

- Respondents should be dewormed or treated of malaria or any infection before conducting research.

- School feeding programmes should be introduced and the parents, guardians, teachers and school vendors should be educated on the importance of good nutrition to improve their dietary habits since majority of the respondents frequently purchase their breakfast from school.

- More research on the prevalence of micronutrient deficiencies tagged "hidden hunger" should be done and encouraged by the Federal Government through sponsorship. 


\section{REFERENCES}

Abramson SD, Abramson N, "common and uncommon anaemia. Am Fam Physician1999.59; 851-8 (PubMed abstract)

Adelakun D. A., Thurnham D. I. (1990) Plasma ferritin concentrations in anaemic children: relative importance of malaria, riboflavin deficiency, and other infections. Am. J. Clin. Nur.51:453-456.

Aggett PJ. Iron. In: Erdman JW, Macdonald IA, Zeisel SH, eds. Present Knowledge in Nutrition. 10th ed. Washington, DC: Wiley-Blackwell; 2012:506-20.

Annibale B, Capurso G, Chistolin A, D'Ambra G, DiGiuoli E. Monarca B. DelleFave G. Gastrointestinal causes of refractory iron deficiency anaemia in patients without gastrointetinal symptoms Am J. Med 2001; 111:439-45 (PubMed abstract)

Asobayire F, Adou P, Davidson L, Cook J and R Flurrel Prevalence of iron deficiency with and without concurrent anaemia in population groups with high prevalence of malaria and other infections: a study in Cote d'ivore. Am. J. Clin. Nutr. 2001; 74:776-782.

Atkinson SH, Rockett K, Sirugo G, Bejon PA, Fulford A, O'Connell M A, Bailey R, Kwiatkowski DP, Prentice AM. Seasonal Childhood Anaemia in West Africa Is Associated with the Haptoglobin 22 Genotype. PLoS Med 2006;3:el72.

Ayatse J.O.I, Ekanem E.E. (1994) Plasmodium falciparum malaria: its effects on some haematological parameters in normal and side cell Nigerian children. Trop. Med. Parasitol 45:219-222. MedlineGoogleSchollar.

Baynes R., Bezwoda W., Bothwell T., Khan Q., Mansoor N. (1986) The non-immune inflammatory response: serial changes in plasma iron, iron-binding capacity, lactoferrin and C-reactive protein. Scand. J. Clin Lab. Invest. 46:695-704. CrossRefMedlineGoogle Scholar.

Bhaskaram p. Immunobiology of mid micronutrient deficiencies. Br J Nutri 2,001:85:875 -80. PubMed abstract

Bolt I, Diallo D, Tchemia G. Iron deficiency in pregnancy: effects on the newborn. CurrOpinHamatol1999;6:65-70 (PubMed abstract)

Bothwell TH, Charton RW, CiijHDmFubcg CA. Iron Metabolism in Man. St. Louis: Oxford:Blackwell Scientific, 1999.

Brabin, B. J. (1992) The role of malaria in nutritional anemias. In: Nutritional Anemias (Fomon, S. J. \&Slotkin, S., eds.), pp. 65-80. Raven Press, New York, NY.

Brotanek JM, Gosz J, Weitzman M, Flores G. Iron deficiency in early childhood in the United States: risk factors and racial/ethnic disparities. Pediatrics 2007; 120:568-75. [PubMed abstract]

Centers for Disease Control and Prevention (CDC). Recommendations to prevent and control iron deficiency in the United States. MMWR Recomm Rep 1998;47:1-29. [PubMed abstract] 
Clark SF. Iron Deficiency Anemia. Nutr Clin Pract2008;23:128-41. [PubMed abstract]

Conrad ME. Iron deficiency anaemia, 2006:

Cook J. D., Lipschitz D. A., Miles L.E.M., Finch C. A. (1974) Serum ferritin as a measure ofiron stores in normal subjects. Am. J. Clin. Nutr. 27:681-687.

Cook JD, Rddy MB, Burr J, Juillerat MA, Hurrell RF. The influence of different cereal grains on iron absorption from infant cereal foods. Am J. Clin Nutr1997;65:964-9. (PubMed Abstract)

Corbett .TV. Accidental poisoning with iron supplements. MCN Am J Matern Child Nurs 1995; 20:234. (PubMed abstract)

Dallman PR. Biochemical basis for the manifestation of iron deficiency. Annu Rev Nutr1986;6:13-40 (PubMed abstract)

De Onis M, Onyango AW, Borghi E, Siyam A, Nishida C, Siekmann J. Development of WHO growth reference for school -aged children and adolescents. Bull World Health Organ 2007;85:660-7

DeMaeyer E. M., Adiels-Tegman M. (1985) The prevalence of anaemia in the world. Rapp. Trimest. Stat. Sanit. Mond. 38:302-316. Google Scholar

DeMaeyer EM Preventing and controlling iron deficiency through primary healthcare. A guide for health administrators and programme managers, Geneva. WHO 19S59.

Drakesmith H, Prentice AM. Hepcidin and the Iron-Infection Axis. Science 2012;338:768-72. [PubMed abstract]

Eicher-Miller HA, Mason AC, Weaver CM, McCabe GP, Boushey CJ. Food insecurity is associated with iron deficiency anemia in US adolescents. Am J Clin Nutr2009;90:1358-71. [PubMed abstract]

Fleming A. F. (1982) Iron deficiency in the tropics. Clin. Haematol. 11:365-388. MedlineGoogle Scholar

Fleming AF Haematological manifestation of malaria and other parasite diseases. Clin. Haematol. 1981; 10:983-1009.

Fleming DJ, Jacques PF, Tucker KL, Massaro JM, D'Agostino RB, Sr., Wilson PW, et al. Iron status of the free-living, elderly Framingham Heart Study cohort: an iron-replete population with a high prevalence of elevated iron stores. Am J Clin Nutr2001;73:638-46. [PubMed abstract]

Gabay T, Ginsburg H. Haemoglobin denaturation and iron release in acidified red blood cell lysate - a possible source of iron for intraerythrocytic malaria parasites. Exp Parasitol1993;77:261-72.

Gera T, Sachdev HP. Effect of iron supplementation on incidence of infectious illness in children: systematic review. Bmj2002;325:1142. 
Gibson RS. Assessment of Iron Status. In: Principles of Nutritional Assessment. 2nd ed. New York: Oxford University Press; 2005:443-76.

Gillooly M, Bothwell TH, Torrance JD, MacPhail AP, Derman DP, Bezwocte. WR, et al. The effects of organic acids, phytates and polyphenols on the absorption of iron from vegetables. Br J Nutr 1983 49:331-42. [PubMed abstract]

Granmam-McGregor S, Ani C. A review of studies on the effect of iron deficiency on cognitive development in children. J Nutr. 2001; 131 (2S-2):649S-6S.

Hallberg L, Brune M and L Rossander: Effect of ascorbic acid on iron absorption from different types of meals. Hum. Nutr. Appl. Nutr. 1980; 40A: 97-113.

http://www.emedicine.com/med/fulltopic1188.htm.(cited March 2014) 